\title{
First record of the pelagic thresher shark Alopias pelagicus (Pisces: Alopiiformes: Alopiidae) from the Lakshadweep Sea, India
}

\author{
K.V. ANEESH KUMAR ${ }^{1}$, S. PARESH KHANOLKAR ${ }^{1}$, P. PRAVIN ${ }^{1}$, B. MEENAKUMARI ${ }^{2}$ \\ AND E.V. RADHAKRISHNAN ${ }^{3}$ \\ ${ }^{1}$ Central Institute of Fisheries Technology, CIFT Junction, Matsyapuri PO, Cochin-682029, India, ${ }^{2}$ Indian Council of Agricultural \\ Research, Krishi Anusandhan Bhavan-II, New Delhi-110012, India, ${ }^{3}$ Central Marine Fisheries Research Institute, Cochin-682018, \\ India
}

\begin{abstract}
The pelagic thresher shark Alopias pelagicus is a large, wide-ranging Indo-Pacific Ocean pelagic shark. In this paper, the first record of the pelagic thresher shark, caught from the Lakshadweep Sea is reported. The shark $275 \mathrm{~cm}$ in total length was caught by drift longline operation at depth of $60 \mathrm{~m}$ in the Lakshadweep Sea ( $10^{\circ} 52 \mathrm{~N}$ latitude $72^{\circ} 13 \mathrm{E}$ longitude).
\end{abstract}

Keywords: Alopias pelagicus, Lakshadweep Sea

Submitted 31 October 2011; accepted 17 November 2011

\section{INTRDDUCTION}

Family Alopiidae includes three species of thresher sharks viz., pelagic thresher Alopias pelagicus (Nakamura, 1935), bigeye thresher, A. superciliosus and thresher shark A. vulpinus. Distribution of pelagic thresher is largely restricted to the Indian and Pacific Oceans (Compagno, 2001). The pelagic thresher is highly migratory inhabiting in both coastal and oceanic waters in temperate and tropical seas. It can grow very large in size $\left(\mathrm{L}_{\max }=365 \mathrm{~cm}\right.$ total length (TL) $)$ and the growth rate is comparatively very low $\left(\mathrm{K}=0.10\right.$ year $\left.^{-1}\right)$ showing late sexual maturity (8.0-9.2 years for females and 7.0-8.0 years for males) and usually producing about two embryos per litter (Liu et al., 1999).

The occurrence of this species in the Indian Ocean has been documented by Pillai \& Honma (1978), John \& Varghese (2009), Huang \& Liu (2010), Romanov et al. (2010) and others. Shark distribution is said to be high in the north of the equator (Pillai \& Honma, 1978). This species is reported from the Indian Exclusive Economic Zone by Vijayakumaran (1994), Pillai \& Parakkal (2000), Bhargava et al., (2002), Manojkumar \& Pavithran (2006), Kizhakudan et al. (2007) and Joshi et al. (2008), and contributes considerably to the elasmobranch fishery of India. Alopias vulpinus is the only species of thresher shark previously reported from the Lakshadweep Sea (Jones \& Kumaran, 1980). In this paper, evidence of the occurrence of Alopias pelagicus in the Lakshadweep Sea is presented.

\section{MATERIALS AND METHDDS}

A male pelagic thresher shark Alopias pelagicus was landed during longline operation in the Lakshadweep Sea by fishermen from Agatti Island on 4 April 2011 (Figure 1). The shark was caught on the 3.4 Sun Japanese tuna hook and the location of capture was recorded as $10^{\circ} 52 \mathrm{~N}$ latitude; $72^{\circ} 13 \mathrm{E}$ longitude. The morphometric measurements of the shark were made with a measuring tape to the nearest millimetre (Compagno, 1984) and weight was measured to the nearest gram. The species identification was carried out based on Compagno (1984).

\section{RESULTS}

The morphometric measurements of the specimen are given in Table 1. The TL of the specimen was $275 \mathrm{~cm}$ and standard length was $160 \mathrm{~cm}$. The size of the shark was bigger than earlier reported from the Arabian Sea by Joshi et al. (2008).

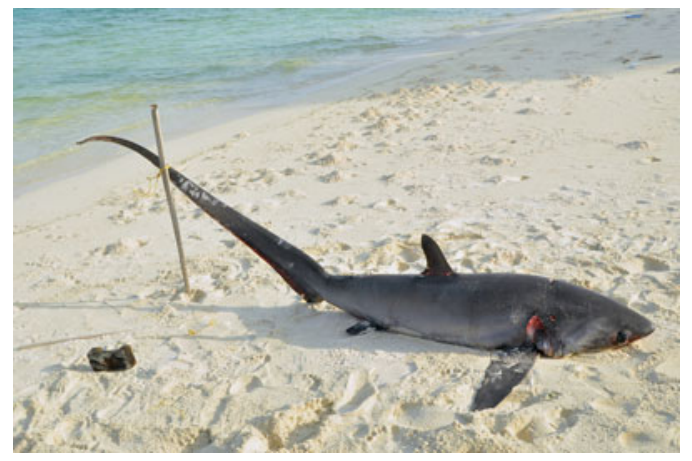

Fig. 1. Pelagic thresher shark, Alopias pelagicus. 
Table 1. Morphometric measurements of Alopias pelagicus.

\begin{tabular}{lll}
\hline Measurements & Cm & \% of total length \\
\hline Total length & 275 & 100 \\
Standard length & 160 & 58.2 \\
Snout to mouth & 13 & 4.7 \\
Snout to eye & 11 & 4 \\
Snout to 1st gill-slit & 36 & 13.1 \\
Snout to pectoral & 44 & 16 \\
Snout to 1st dorsal & 75 & 27.3 \\
Snout to pelvic & 110 & 40 \\
Eye diameter & 4.7 & 1.7 \\
Between dorsal bases & 35 & 12.7 \\
Pectoral to pelvic & 51 & 18.5 \\
Pelvic to anal & 20 & 7.3 \\
Inter-nasal distance & 5 & 1.8 \\
Mouth width & 11 & 4 \\
1st dorsal base & 15 & 5.3 \\
2nd dorsal base & 2 & 0.7 \\
Anal base & 1.9 & 0.7 \\
Pectoral base & 20 & 7.1 \\
Caudal upper lobe & 141 & 51.3 \\
\hline
\end{tabular}

The species has moderately large eyes reaching up to the dorsal surface of the head. Head is convex and the forehead is moderately convex in the lateral view. An inconspicuous horizontal groove is present on each side of the head above the gills. Labial furrows are absent. Snout is moderately long and conical. Pectoral fins are not falcate and the tips are broad and straight. Terminal lobe of the caudal fin is very small. Ventral side is white in colour and is not extending beyond the pectoral fin bases.

\section{DISCUSSION}

The pelagic thresher shark is a large, wide-ranging Indo-Pacific Oceanic species, which is highly migratory, with low fecundity and a low annual rate of population increase. The thresher sharks are listed as 'Vulnerable' globally because of their declining populations (IUCN, 2011). Our study presents the first record of Alopias pelagicus from the Lakshadweep Sea.

\section{ACKNDWLEDGEMENTS}

The authors are grateful for the encouragement given by the Director, CIFT, Cochin and Mr Mark, Department of Conservation, UK for help in species identification. The financial assistance received from NAIP, ICAR, and the Government of India is gratefully acknowledged.

\section{REFERENCES}

Bhargava A.K., Somvanshi V.S. and Varghese S. (2002) Pelagic sharks by-catch in the tuna longline fishery of the Indian EEZ. In Pillai N.G.K., Menon N.G., Pillai P.P. and Ganga U. (eds) Management of scombroid fisheries. Cochin, Kerala, India: Central Marine Fisheries Institute, pp. 165-176.

Compagno L.J.V. (1984) FAO species catalogue. Volume 4. Sharks of the world. An annotated and illustrated catalogue of shark species known to date. Part 1. Hexanchiformes to Lamniformes. Rome: FAO. FAO Fisheries Synopsis, no. 125, Part 1, 249 pp.

Compagno L.J.V. (2001) FAO species catalogue for fisheries purposes. No. 1, Volume 2. Sharks of the world: an annotated and illustrated catalogue of the shark species known to date. Bullhead, mackerel and carpet sharks (Heterodontiformes, Lamniformes and Orectolobiformes). Rome: FAO. FAO Species Catalogue for Fishery Purposes, 269 pp.

Huang H.W. and Liu K.M. (2010) Bycatch and discards by Taiwanese large-scale tuna longline fleets in the Indian Ocean. Fisheries Research 106, 261-270.

IUCN (2011) IUCN Red List of Threatened Species. Version 2011.1. Available at www.iucnredlist.org (accessed 13 October 2011).

John M.E. and Varghese B.C. (2009) Decline in CPUE of oceanic sharks in the Indian EEZ: urgent need for precautionary approach. Mahé, Seychelles: Indian Ocean Tuna Commission Working Party on Ecosystems and Bycatch, 17 pp.

Jones S. and Kumaran M. (1980) Fishes of the Laccadive Archepelago. Kerala, India: Nature Conservation and Aquatic Sciences Service.

Joshi K.K., Balachandran K. and Raje S.G. (2008) Changes in the shark fishery at Cochin. Journal of the Marine Biological Association of India 50, $103-105$.

Kizhakudan S.J., Rajapackiam S. and Rajan S. (2007) Landing of thresher sharks at Chennai. Marine Fisheries Information Service, Technical and Extension Series, 194, p 1.

Liu K.M., Chen C.T., Liao T.H. and Joung S.J. (1999) Age, growth, and reproduction of the pelagic thresher shark, Alopias pelagicus in the northwestern Pacific. Copeia 1999, 68-74.

Manojkumar P.P. and Pavithran P.P. (2006) First record of thresher shark, Alopias vulpinus, from Malabar coast with note on its fishery and biology. Marine Fisheries Information Service, Technical and Extension Series, 190, pp. 17-19.

Pillai P.P. and Honma M. (1978) Seasonal and areal distribution of the pelagic sharks taken by the tuna longline in the Indian Ocean. Bulletin of the Far Seas Fisheries Research Laboratory 16, 33-48.

Pillai P.P. and Parakkal B. (2000) Pelagic sharks in the Indian Seas-their exploitation, trade, management and conservation. CMFRI Special Publication, 70, 95 pp.

Romanov E., Bach P., Rabearisoa N., Rabehagasoa N., Filippi T. and Romanova N. (2010) Pelagic elasmobranch diversity and abundance in the Indian Ocean: an analysis of long-term trends from research and fisheries longline data. Indian Ocean Tuna Commission Working Party on Ecosystems and Bycatch, IOTC-2010, WPEB 16, $19 \mathrm{pp}$.

and

Vijayakumaran K. (1994) On a pelagic thresher shark Alopias pelagicus caught off north of Kakinada. Marine Fisheries Information Service, Technical and Extension Series 133, 1.

\section{Correspondence should be addressed to:}

K.V. Aneesh Kumar

Central Institute of Fisheries Technology

CIFT Junction, Matsyapuri PO, Cochin-682029, India

email: menoncift@gmail.com 